\title{
A Combined Renewable Energy System Demonstration for Providing the Energy Need at Esentepe (Windhill) Campus in Sakarya University
}

\author{
Çiğdem Özer ${ }^{1 *}$, Baha Kanberoglu² \\ ${ }^{1}$ Environmental Engineering Department, Engineering Faculty, Sakarya University, Sakarya, Turkey \\ *cozer@sakarya.edu.tr \\ ${ }^{2}$ Electric-Electronics Engineering Department, Engineering Faculty, Sakarya University, Turkey \\ bkanberoglu@sakarya.edu.tr
}

Received: 9 April 2018

Accepted: 12 June 2018

DOI: $10.18466 /$ cbayarfbe.413774

\begin{abstract}
Energy need of the world is directly increasing with population and technology. Limited traditional sources like fossil fuel are not sustainable and usage of these sources causes harmful conditions for environment. The continuous and increasing energy usage must be provided from the continuous, natural and renewable energy sources instead of traditional sources. Wind and solar energy applications are important types of renewable energy class with features like being clean and environmentally friendly. Because of these remarkable features, these renewable energy sources are preferred and used all over the world. In Turkey, an outstanding increase has taken place in installed power during last 10 years. In this study, the electricity requirement of a building on the campus of Sakarya University is aimed to be compensated with a combined solar/wind energy system. First, the amount of energy consumption of selected building in a year was evaluated. The required parameters for wind energy like wind speed were provided from the Ministry of Energy and Natural Resources page. And, solar energy parameters were taken from Institute for Energy and Transport (IET) established by European Commission. The calculations were made by using these parameters and return of the investment was determined.
\end{abstract}

Keywords: Renewable energy, wind and solar energy, electricity consumption.

\section{Introduction}

Today, in parallel with globalization, increasing population, technological, economic and social developments, our need for electricity increases day by day [1]. The use of fossil-based energy sources has resulted in large quantities of greenhouse gas emissions and global warming, defects in air quality, contamination of water resources have emerged therefore this energy required to be produced by taking into account the environmental impacts and in an uninterrupted, high quality, reliable and economic environment at the same time. [2,3]. As a result of increase in the importance of cleaner environment, the effect of international directives and incentives in this area, the studies on renewable energy sources have increased [4]. Many projects have been undertaken to increase the use of renewable energy sources, such as solar panels to benefit from the sun and windmills to use the wind energy [3].

Wind and sun are advantageous renewable energy sources with some features. For example, they are unlimited sources, do not require very high technology for energy production and are not hazardous for the environment and biodiversity if it can be projected for a suitable area [5-7]. These features have made the wind and sun commonly used energy sources both in the world and in our country. The installed power of wind power plants operating in the world by the end of 2014 is approximately $370 \mathrm{GW}$ [8]. In Turkey, wind energy is one of the main sources of energy production, which accounts for about $4 \%$ of the installed power as a result of significant investments in the same period [9]. The evaluation of Wind Energy Power Plants in Turkey over the years in terms of installed power can be seen in Figure 1 [10]. The Marmara region, in which Sakarya is located, is the second richest region in terms of wind power and speed after Ege region in Turkey. For this reason, 36.95\% of the wind power plants are in this region $[10,11]$.

By the end of 2016, with the establishment of unlicensed power generation plants, the number of solar power plants is seen as 1043, while the installed power of these power plants is $819.6 \mathrm{MW}$ and total installed power together with 2 licensed solar energy power plants reached 832.5 MW [12]. 


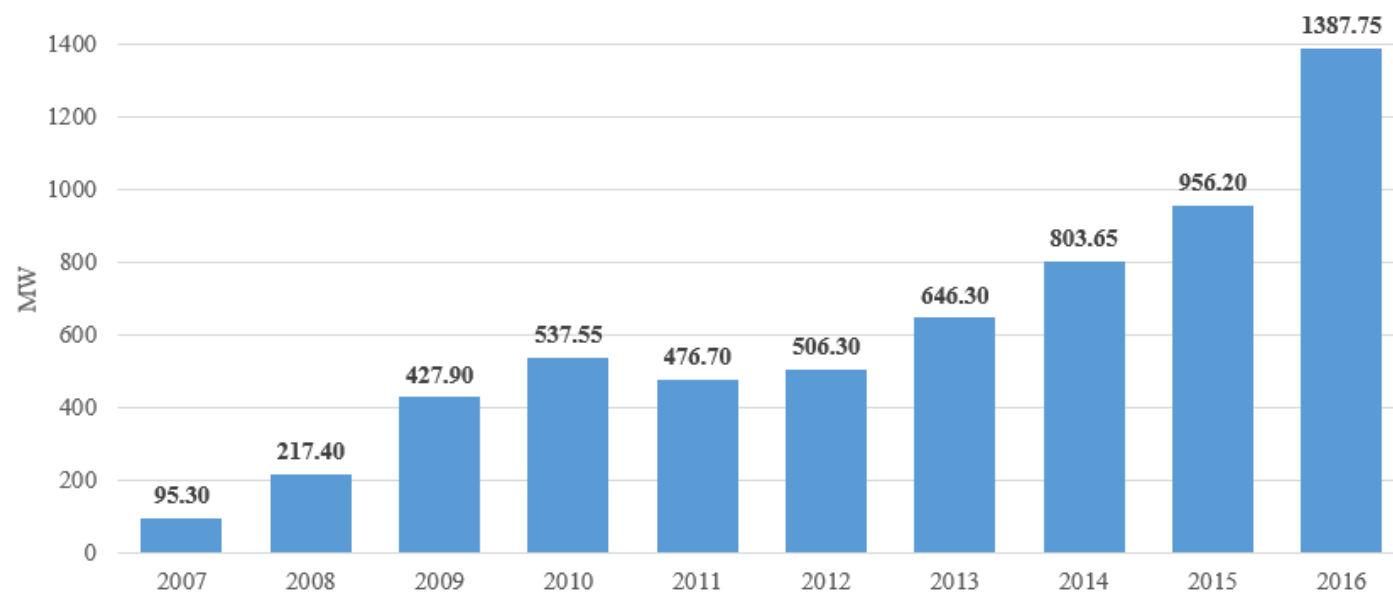

Figure 1. Annual Installations for Wind Power Plants in Turkey (MW).

In the light of this information, the necessary planning was made to compensate the electricity requirement with a combined solar/wind energy system for a building on the campus of Sakarya University. The annual energy consumption of the selected building was determined for this purpose. The average wind speed data on campus was taken from the wind energy potential map on the Ministry of Energy and Natural Resources page. The characteristics of the wind turbine to be installed have been determined according to the amount of energy consumed and the wind speed value.

Solar energy parameters were taken from Institute for Energy and Transport(IET) established by European Commission [13]. The monthly photovoltaic energy was calculated for desired location via PVGIS application generated by IET. Lastly, the calculations were made by using these parameters and return of the investment was evaluated.

\section{Materials and Methods}

The building to be used as a model for energy project was chosen as Campus Hotel. The annual energy requirement of this hotel for 2016 has been obtained from Directorate of Construction and Technical Works of Sakarya University. Though the current annual consumption of the hotel was $26000 \mathrm{~kW}$, planning was done considering the different electrical needs that can occur and the fact that it works as full capacity. The possibility of an overuse of $15 \%$ is considered and calculation has been made based on an energy consumption of 30000 $\mathrm{kWh} /$ year.

A system was considered where solar and wind energy was used together to meet the annual electricity need of the campus hotel building. The installation of this system aimed to ensure the continuity of energy production and to respond energy needs even in changing weather conditions. Both solar and wind energy systems have been established over the annual consumption data.

\subsection{Solar Energy}

The solar system has been planned for 25 years with $1 \%$ loss of efficiency each year. Despite the annual losses, $30000 \mathrm{kWh} /$ year production has been targeted for the last year of 25 years period. Total capacity of the solar energy system was calculated due to these targets. First, the solar energy potential in the area where the solar power plant is planned to be installed has been identified. It is necessary to know how much sunlight is received monthly and annually on the place where the solar power plant is planned to be installed. With this data, the estimated gain and losses of the power plant and also the solar panel types can be determined.

Table 1. Monthly PV energy and solar irradiation of the Solar Power Plant Area.

\begin{tabular}{|c|c|c|c|c|c|}
\hline Month & $\boldsymbol{E}_{\boldsymbol{m}}$ & $\boldsymbol{H}_{\boldsymbol{m}}$ & Month & $\boldsymbol{E}_{\boldsymbol{m}}$ & $\boldsymbol{H}_{\boldsymbol{m}}$ \\
\hline Jan & 1870 & 70.1 & Jul & 4790 & 198 \\
\hline Feb & 2150 & 81.7 & Aug & 4700 & 195 \\
\hline Mar & 2920 & 113 & Sep & 3800 & 155 \\
\hline Apr & 3660 & 146 & Oct & 2900 & 115 \\
\hline May & 4070 & 166 & Nov & 2520 & 96.3 \\
\hline Jun & 4340 & 180 & Dec & 1860 & 69.7 \\
\hline & & Total & $\mathbf{3 9 5 8 0}$ & $\mathbf{1 5 8 5 . 8}$ \\
\cline { 4 - 6 }
\end{tabular}

Solar energy potential data were obtained using the PVGIS application of the Institute for Energy and Transport (IET) established by the European Commission. The monthly solar energy potential of the zone is calculated by taking into account the estimated energy losses with PVGIS application. Taking into account annual efficiency losses, it was decided to establish a solar power plant producing $32000 \mathrm{kWh} \mathrm{/}$ year. Monthly PV energy and solar irradiation values of the Solar Power Plant Area is given at Table 1.

$\mathrm{E}_{\mathrm{m}}$ and $\mathrm{H}_{\mathrm{m}}$ are average monthly electricity production $[\mathrm{kWh}]$ and average monthly sum of global irradiation per 
square meter received by the modules of the given system $\left[\mathrm{kWh} / \mathrm{m}^{2}\right]$, respectively.

\subsection{Wind Energy}

Both wind potential and topographical structure must be known to install a wind turbine. The area where the wind turbine is to be constructed should be suitable for transportation and transportation activities also must be efficient in terms of wind regime. The scientific data is needed to know this [14].

Wind speed data for the planned area of turbine placement provided from wind energy potential map on the Ministry of Energy and Natural Resources page [15]. Since the Esentepe campus is in the west of Sakarya province, the wind speed was accepted as $4.5 \mathrm{~m} / \mathrm{s}$ by using the map and color scale and the planning was made according to this value.

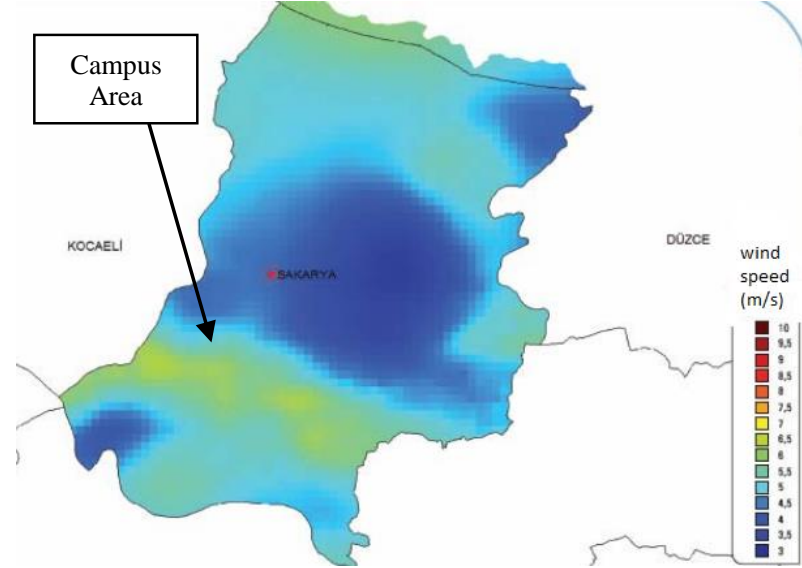

Figure 2. Wind source information for Sakarya.

The daily electricity demand was calculated from the annual electricity consumption and the turbine power was determined by using the wind speed data. Since the campus area is generally windy, calculations were made assuming that the turbine was operating for 16 hours and resting for 8 hours. The calculations made with these assumptions and the electricity need expected to be produced by turbine per hour was found to be $5.13 \mathrm{~kW}$.

Table 2. The power values that different power wind turbines can produce at different speeds.

\begin{tabular}{|c|c|c|c|c|c|c|c|c|}
\cline { 2 - 10 } \multicolumn{1}{c|}{} & \multicolumn{9}{c|}{ Turbines } \\
\cline { 2 - 10 } \multicolumn{1}{c|}{} & $5 \mathrm{~kW}$ & $10 \mathrm{~kW}$ & $20 \mathrm{~kW}$ & $30 \mathrm{~kW}$ & $50 \mathrm{~kW}$ & $50 \mathrm{~kW}$ & $50 \mathrm{~kW}$ & $60 \mathrm{~kW}$ \\
\cline { 2 - 10 } & A & B & C & B & C & D & E & F \\
\hline Wind Speed (m/ $\mathbf{s})$ & \multicolumn{6}{|c|}{} & \multicolumn{5}{c|}{ Power (kW) } \\
\hline $\mathbf{1}$ & 0 & 0 & 0 & 0 & 0 & 0 & 0 & 0 \\
\hline $\mathbf{2}$ & 2 & 0 & 0 & 0 & 0 & 0 & 0 & 0 \\
\hline $\mathbf{3}$ & 8 & 198 & 100 & 754 & 0.3 & 1.6 & 1.9 & 1.8 \\
\hline $\mathbf{4}$ & 18 & 485 & 300 & 2157 & 1.6 & 3.9 & 4.4 & 7.0 \\
\hline $\mathbf{5}$ & 35 & 1020 & 1600 & 4258 & 4.4 & 8.2 & 8.6 & 13.2 \\
\hline $\mathbf{6}$ & 61 & 1850 & 3500 & 7367 & 8.6 & 14.3 & 15.0 & 25.7 \\
\hline $\mathbf{7}$ & 97 & 3098 & 6000 & 11651 & 14.2 & 23.5 & 23.7 & 40.0 \\
\hline $\mathbf{8}$ & 145 & 4852 & 9400 & 16353 & 21.5 & 35.4 & 35.3 & 56.8 \\
\hline $\mathbf{9}$ & 206 & 7320 & 13500 & 23307 & 30.3 & 48.1 & 49.8 & 60.0 \\
\hline $\mathbf{1 0}$ & 283 & 10080 & 17800 & 33018 & 40.1 & 59.0 & 50.1 & 60.0 \\
\hline
\end{tabular}

The power values produced by the different turbines at the possible wind speeds were given in Table 2. As a result of examining the turbines at various powers, it was understood that the wind turbine in the $60 \mathrm{~kW}$ range would be able to respond to needed energy as seen Table 2 . The wind speed- power curve of the selected turbine can be seen in Figure 3.

The power generated by the selected turbine against the wind speed of $4.5 \mathrm{~m} / \mathrm{s}$ is about $10 \mathrm{~kW}$, seen from the power curve. It means that the amount of energy generated by the turbine will be $58400 \mathrm{~kW}$ annually.

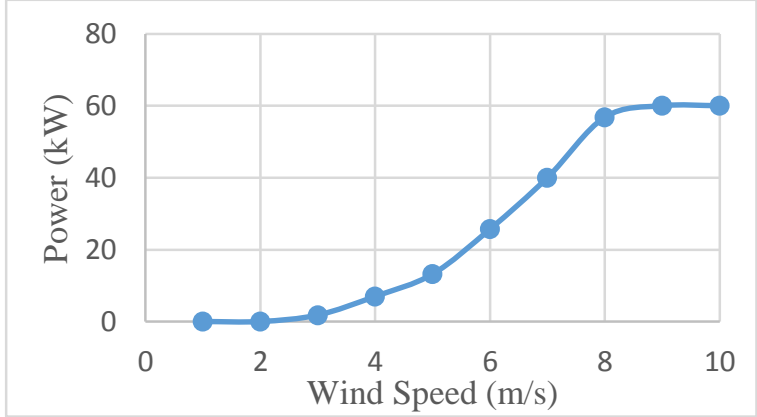

Figure 3. The wind speed- power curve of the selected turbine $(\mathrm{F})[16]$. 


\section{Results and Discussion}

\subsection{Cost Analysis}

Solar and wind energy plants are designed to meet the building's energy need separately. Renewable energy productions are planned to be sold to the state. With the law issued by the state in May 2005, purchase prices for wind and solar energy have been announced[17]. If domestic products are used, the purchase price is also increasing. At the end, the amount of annual consumption is deducted from the amount of energy sold. There is no rental fee for both solar and wind energy plants because it was planned to be installed on university land.

Installation cost of solar power plant includes solar panel, inverter, construction cost, cabling, protection equipment, transformer and cabinet, counter, panel, wire mesh [18]. The installation cost of Solar Power Plant is given at Table 3 .
Table 3. The installation cost of Solar Power Plant.

\begin{tabular}{lc}
\hline Solar Power Plant & Euro/kWh \\
\hline Solar Panel & 600 \\
Transformer cost & 30 \\
Inverter & 200 \\
Construction & 75 \\
Transmission lines & 50 \\
Other (Protection $\quad$ Equipment, & 80 \\
Monitoring, etc.) & \\
Labour + Transportation Cost & 60 \\
\hline Total & 1100 \\
\hline
\end{tabular}

It was seen that the cost of a solar power plant system to be installed was 1100 Euro/kWh. The energy obtained using solar energy is sold to the state at a minimum of 13.3 USD cents $/ \mathrm{kWh}$. If domestic production materials are used, this amount goes up to 15.4 USD cents/kWh. As seen in Table 4, the production cost will be met at the end of 8 years.

Table 4. Return of Investment Cost (Solar Power Plant).

\begin{tabular}{cccccc}
\hline Year & Energy Production KWh/Year & Annual Income $€$ & $\begin{array}{c}\text { Invesment Cost } \\
£\end{array}$ & $\begin{array}{c}\text { Maintenance Cost } \\
£ / Y e a r\end{array}$ & Return of Invesment $\ddagger$ \\
\hline $\mathbf{1}$ & 39580.0 & 24381.3 & -174240.0 & -1742.4 & -151601.1 \\
$\mathbf{2}$ & 39184.2 & 24137.5 & -151601.1 & -1742.4 & -129206.1 \\
$\mathbf{3}$ & 38788.4 & 23893.7 & -129206.1 & -1742.4 & -107054.8 \\
$\mathbf{4}$ & 38392.6 & 23649.8 & -107054.8 & -1742.4 & -85147.4 \\
$\mathbf{5}$ & 37996.8 & 23406.0 & -85147.4 & -1742.4 & -63483.7 \\
$\mathbf{6}$ & 37601.0 & 23162.2 & -63483.7 & -1742.4 & -42063.9 \\
$\mathbf{7}$ & 37205.2 & 22918.4 & -42063.9 & -1742.4 & -20887.9 \\
$\mathbf{8}$ & 36809.4 & 22674.6 & -20887.9 & -1742.4 & 44.3 \\
$\mathbf{9}$ & 36413.6 & 22430.8 & 44.3 & -1742.4 & 20732.7 \\
$\mathbf{1 0}$ & 36017.8 & 22187.0 & 20732.7 & -1742.4 & 41177.2 \\
\hline
\end{tabular}

Installation cost of wind turbine includes turbine, inverter, construction cost, cabling, protection equipment, transformer and cabinet, counter, panel, wire mesh. Approximate equipment prices are included in the price of the wind turbine as seen in Table 5.

Table 5. The installation cost of Wind Turbine.

\begin{tabular}{|c|c|}
\hline Turbine power & $50 \mathrm{~kW}$ \\
\hline Turbine cost (include installation) & $260,000 €$ \\
\hline Transformer cost & $15,000 €$ \\
\hline Transmission lines & $15,000 €$ \\
\hline Construction works & $10,000 €$ \\
\hline Total & $300,000 €$ \\
\hline
\end{tabular}

The energy obtained via using wind turbines is sold to the state at a 7.3 USD cents/kWh [22]. With domestic production materials usage, the price goes up to 11 USD cents/kWh.
As seen in Table 6, the production cost for wind turbine will be amortized at the end of 14 years.

Combined solar/wind system cost is calculated as about $470000 £$. The yearly maintenance cost is added to the total cost in return investment calculation. The production cost for solar/wind combined system will be amortized at the end of 11 years.

Also, annual electricity usage cost must be included to the calculations. Annual electricity cost is calculated by the product of annual consumption and electricity unit price. Annual electricity cost is added to the investment cost and redemption period is calculated as 15 years this time. After all these information and calculations, it can be said that the system will be starting to profit from the 16 th year. 
Table 6. Return of Investment Cost (Wind Turbine).

\begin{tabular}{cccccc}
\hline Year & Energy Production KWh/Year & $\begin{array}{c}\text { Annual Income } \\
£\end{array}$ & $\begin{array}{c}\text { Invesment Cost } \\
£\end{array}$ & $\begin{array}{c}\text { Maintaince Cost } \\
£ / \text { Year }\end{array}$ & Return of Invesment $€$ \\
\hline $\mathbf{1}$ & 58400 & 25696 & -300000 & -3000 & -277304 \\
$\mathbf{2}$ & 58400 & 25696 & -277304 & -3000 & -254608 \\
$\mathbf{3}$ & 58400 & 25696 & -254608 & -3000 & -231912 \\
$\mathbf{4}$ & 58400 & 25696 & -231912 & -3000 & -209216 \\
$\mathbf{5}$ & 58400 & 25696 & -209216 & -3000 & -186520 \\
$\mathbf{6}$ & 58400 & 25696 & -186520 & -3000 & -163824 \\
$\mathbf{7}$ & 58400 & 25696 & -163824 & -3000 & -141128 \\
$\mathbf{8}$ & 58400 & 25696 & -141128 & -3000 & -118432 \\
$\mathbf{9}$ & 58400 & 25696 & -118432 & -3000 & -95736 \\
$\mathbf{1 0}$ & 58400 & 25696 & -95736 & -3000 & -73040 \\
$\mathbf{1 1}$ & 58400 & 25696 & -73040 & -3000 & -50344 \\
$\mathbf{1 2}$ & 58400 & 25696 & -50344 & -3000 & -27648 \\
$\mathbf{1 3}$ & 58400 & 25696 & -27648 & -3000 & -4952 \\
$\mathbf{1 4}$ & 58400 & 25696 & -4952 & -3000 & 17744 \\
$\mathbf{1 5}$ & 58400 & 25696 & 17744 & -3000 & 40440 \\
\hline
\end{tabular}

\section{Conclusion}

This paper is a very simple example of the usability of our renewable energy sources. The project is a design project and demonstrates the benefits of solar and wind energy sources usage in practice. A combined system is preferred to provide uninterrupted energy without being affected by weather conditions and potential system failures. With current energy consumption and pricing system in 2018, the calculated return period of the combined solar/wind energy system for this study is 15 years (from 2018 to 2033) and then combined system will start to make profit. Although a 15 -year payback period is long, it is important that universities lead the way in using an energy system designed with renewable resources that do not harm the environment. This period can be reduced by planning to install more power for supplying more energy need. In other words, a larger scale planning can be more efficient. Sakarya University's energy needs can be supplied by solar and wind energy. The use of natural and inexhaustible energy resources is a way of providing energy needs with environmental and human-friendly methods.

\section{References}

1. Colak, İ., Demirtas, M., Development Of Energy Production Through Wind Energy In Turkey, Turkish Science Research Found., 2008, 1, $55-62$.

2. Solmaz, S., Turan, A., Ortalama Geçmiș Rüzgar Verileri Üzerinden Rüzgar Enerjisi Santralleri İçin Ön Fizibilite Yapılmasi: Gediz Üniversitesi $100 \mathrm{Kw}$ Rüzgar Enerjisi Uygulamas1, 3. İzmir Rüzgâr Sempozyumu, İzmir, Türkiye, 2015, pp. 71-86.

3. Külekçi, Ö.C., Yenilenebilir Enerji Kaynakları Arasında Jeotermal Enerjinin Yeri ve Türkiye Açısından Önemi, Ankara Üniversitesi Çevre Bilimleri Dergisi, 2009, 2, 83-91.

4. Akdag, S. A., Using Weibull Distribution In Wind Energy Potential And Economic Analysis, Master Thesis, 2008.
5. Senel, M.C., Koc, E., The State Of Wind Energy In The World And Turkey, General Evaluation, Engineer and Machinery Magazine, 2013, $663,46-56$.

6. El-Ali, A., Moubayed, N., Outbib, R., Comparison between solar and wind energy in Lebanon, 9th Int Conf Electr Power Qual. Util. EPQU, 2007, Barcelona, Spain.

7. Jacobson, M.Z., Delucchi, M.A., Providing all global energy with wind, water, and solar power, Part I: Technologies, energy resources, quantities and areas of infrastructure, and materials, Energy Policy, 2011, 39(3), 1154-1169.

8. http://www.enerji.gov.tr/tr-TR/Sayfalar/Ruzgar (accessed February 13, 2017).

9. Yağc1, E., Comparison And Error Analysis Of Different Methods Used For Wind Speed Extrapolation, Master Thesis, 2013.

10. Turkish Wind Energy Association, Turkish Wind Energy Statistics Report, 2017.

11. Gençoğlu, M.T., Yenilenebilir Enerji Kaynaklarının Türkiye Açısından Önemi, Firat Universitesi Fen ve Mühendislik Bilimleri Dergisi, 2002, 14(2), 57-64.

12. http://www.enerii.gov.tr/tr-TR/Sayfalar/Gunes (accessed March 29 , 2018).

13. https://ec.europa.eu/jrc/en/scientific-tool/pvgis (accessed March 29, 2018).

14. Kiyak, İ., Oral, B., Topuz V., Yerleșim Bölgelerinde Rüzgar Enerjisi Kullaniminin Yayginlaştirilmasi: Bina Montajli Rüzgar Türbinleri, Türkiye 11. Enerji Kongresi, 2009, İzmir, Türkiye.

15. http://www.eie.gov.tr/YEKrepa/SAKARYA-REPA.pdf (accessed February 23, 2017).

16. http://www.cimo.com.tr/product.php?id product $=316$ (accessed February 24, 2017).

17. Law on utilization of renewable energy sources for the purpose of generating electrical energy, Law No: 5346, Repuclic of Turkey Ministry of Energy and Natural Resources, 2005.

18. http://humartas.com.tr/1-mw-lisanssiz-ges-projeleri/ (accessed March 29, 2018). 